\title{
Lærerrollen der blev væk: Opbygningen af et transformativt lærerideal
}

\author{
(The disappearance of the vocational teacher's role: \\ The construction of a transformative teacher ideal)
}

\section{Tobias Kidde Skov}

VIA University College, Aarhus, Danmark (toks@via.dk)

\begin{abstract}
This article raises the question if the role of the vocational teachers needs another teacher's ideal. The foundation of the article is a rising tendency to describe the teacher's role by other means than being a teacher and making the role of the teacher a matter of bringing students safely and easily to a learning outcome, through a teaching task described as both a supervisor, facilitator, motivator, and consultant.

The article commences by explaining the tendency to understand the vocational teacher by others means than a teacher. Through analysis of ideas from Gert Biesta, Hartmut Rosa and Andrea English, the article will point to a transformative teaching ideal as a way of understanding the role of the vocational teacher, and at the same time try to exemplify this teacher ideal through different types of vocational education. The article will conclude by arguing that a transformative understanding of the teacher's role can be seen as a more embracing ideal as opposed to the current trend of constructivism, and at the same time as an ideal, that gives back the original teaching task to the teacher.
\end{abstract}

Keywords: vocational education, resistance, transformation, discontinuity, resonance 


\section{Indledning}

At skulle forklare en erhvervsskolelærers rolle for mine studerende på Diplomuddannelsen i Erhvervspædagogik er blevet en svær og mere kompleks opgave. Som underviser på uddannelsen oplever jeg ofte de studerendes frustrationer med at forstå, hvordan de skal agere og forholde sig til en rolle som erhvervsskolelærere. De studerende ønsker at tilegne sig pædagogisk og didaktisk viden og erfaring med muligheden for både, at kunne forstå hvad deres rolle som erhvervsskolelærer er, og deraf med muligheden for at kunne "løse" den opgave. Dette ønske præsenteres ofte med en egenmetafor om at få fyldt en værktøjskasse op med tiltag, metoder og forståelser, som kan hjælpen dem i rollen. En rolle som lærerne på erhvervsskolerne gerne vil forstå og lykkes med, men som i dag fremstår mere udefineret end for bare 10 år siden.

I erhvervsskolesammenhænge ses det ofte, at nye pædagogiske retninger og didaktiske metoder diskuteres og indføres en årrække efter, at de har være i grundskolen. Dette ses lige nu med et stort fokus på eksempelvis læringsbegrebet og relaterede begreber om læringsmål, facilitering, undervisningsdifferentiering og feedback. Den øgede interesse for læringsbegrebet, blandt andet med inspiration fra en konstruktivistisk læringsteori (Rømer, 2017), har været med til at udvide definitionen af erhvervsskolelærerens rolle og opgave, og skabt et nyt vokabular for forventningerne til lærerens roller. Det ses eksempelvis når erhvervsskolelæreren beskrives som en faciliterende underviser, der skal gøre læreprocessen let for eleven, med fokus på rammesætning, feedback og evaluering (Kaatmann, 2021). Eller gennem den teori, som de studerende på diplomuddannelsen bliver introduceret for. Her bliver lærerens rolle beskrevet som repræsentant, instruktør, konsulent eller deltager (Beck, 2016, s. 59), som mester, værkføre og konsulent med fokus på undervisningsdifferentiering (Svejgaard, 2011) eller med henvisning til inddragelsen af teknologi i undervisningen, som designer, konsulent, vejleder, facilitator, coach og medlærer (Holm Sørensen m.fl., 2010).

Det nye vokabular understreger et fokus på, hvad eleverne skal lære og, hvordan læreren i forskellige roller kan understøtte eleverne i en proces, som skal gøre det let for eleverne, at opnå forhåndsdefineret mål. Det fornyet fokus på lærerens mange roller, har samtidig unødigt gjort erhvervsskolelæreren til en form for teknikker, designer og tilrettelægger, som udelukkende er til for at understøtte, forsimple og optimere elevernes læring (Rømer, 2017; Tanggaard, 2017). Lektor Thomas Aastrup Rømer sætter denne kausale forståelse af undervisning på formel således: læring 0 - metode (årsag) - læring 1. Hvis der efter metodens intervention, kan konstateres en forandring mellem læring 0 og læring 1, ja så virker metoden (Rømer, 2010, s. 43), og her kan metoden med fordel forstås som den rolle læreren indtager. Som den hollandske uddannelsesfilosof Gert Biesta beskriver det, så er det som om det fornyet fokus på læringsbegrebet, har opgivet forestillingen om, at en lærer kan lære sine elever noget, og at eleverne 
kan lære noget af deres lærer (Biesta, 2014). Biestas bekymring er, at den konstruktivistiskinspirerede læringsforståelse, leder læreren ud i en forlegenhed af egen undervisning og i det hele taget en fortvivlelse omkring identiteten som lærer. Er lærerne blot vejledere, facilitatorer eller konsulenter for elevernes læring, og hvad vil det i det hele taget sige at være erhvervsskolelærer? Det giver identitetsudfordringer for erhvervsskolelæreren, for hvad er formålet som lærer på en erhvervsskole, og hvordan skal man heraf forstå sin rolle?

Hvor omfanget af de nye lærerroller kan få de studerende på diplomuddannelsen til at blive forpustet og anse de rolledefinitioner som både konfuse og komplekse, udvisker det nye vokabular også forståelsen af en egentlig opgave og rolle som erhvervsskolelærer. Hvornår og hvordan påtager læreren sig alle disse forskellige roller og er rollerne blot nogle kasketter, som hurtigt kan skiftes ud, alt efter elevernes læringspotentiale og proces? De mange lærerroller som det overnævnte læringssyn inspirerer til, kalder på en anden formulering af erhvervslærerens rolle og et ideal, som ikke kun sigter på, at understøtte eleverne mod let at nå forskellige målpinde, men også udvikler dem og åbne verden op for dem i alt sin udfordrethed og kompleksitet. Eleverne skal ikke kun formes og disciplineres frem mod noget specifikt, men også udfordres til at blive handlende subjekter, som oplever uddannelse som noget vanskeligt og frustrerende (Biesta, 2014). Med udgangspunkt i tanken om, at eleverne igennem deres erhvervsuddannelse skal møde modstand og vanskeligheder, vil artiklen formulere et transformativt lærerideal, som et grundlag for at forstå erhvervsskolelærerens rolle.

\section{Et transformativt udgangspunkt}

For at argumentere for et transformativt lærerideal er det væsentligt først kort at forstå hvad der menes med lærerens rolle, og samtidig tydeliggøre en skelnen mellem forståelsen af et transformativt lærerideal og den transformative læringsteori.

Når der i artiklen arbejdes med lærerens rolle forstås det ind i en ramme, hvor lærerrollen kan beskrives som den kulturelle, psykologiske, dannelsesmæssige og metodiske forvaltning af den opgave, det er at være erhvervsskolelærer. Lærerens rolle bliver at forsøge at lære, danne og udvikle eleverne, så de får de bedste forudsætninger for et kommende arbejdsliv, og rollen bliver på den baggrund at skabe og understøtte et undervisningsmiljø, som eleverne kan lære, danne og udvikle sig i. Med et transformativt lærerideal som grundlag indebærer rollen som erhvervsskolelærer at planlægge en undervisning, som kan indgyde modstand og vanskeligheder hos eleverne og udfordre dem.

Dette betyder ikke, at læreren ikke forsat skal forholde sig til de målpinde, som er en grundlæggende del af undervisningen på erhvervsuddannelserne, men formålet her er at konkretisere lærerens rolle og forsøge at simplificere lærerrollen, så den opleves mindre omfangsrig og udefineret. 
I et forsøg på at konkretisere hvad der menes med et transformativt lærerideal er det relevant at skelne mellem et transformativt lærerideal og den transformative læringsteori. Når transformationer handler om læringsprocesser arbejdes der psykologisk med læringsbegrebet, og deraf hvordan eleverne kognitivt ændrer sig i takt med, at de møder noget nyt og anderledes i undervisningen. Billedligt bliver denne proces ofte skitseret som en puslespilsbrik, som ikke passer ind med de øvrige brikker i hovedet på eleven, men som efter forskellige bearbejdninger af den nye viden alligevel kommer til at passe sammen. Eleven må i denne proces tilbage og forholde sig til tidligere viden og erkendelser, og eventuelt ændre grundopfattelser i arbejdet med, at få brikkerne til at passe. Den transformativ læring tildeler på den måde refleksion en bestemt funktion, nemlig det at revurdere de overbevisninger og forforståelser vi har, og via handlinger og bearbejdninger skabe nye indsigter og begrundelser. Processen kan minde om den Aastrup Rømer beskrev ovenover, men her dog med det udgangspunkt, at eleverne møder forskellige former for indhold og opgaver, som ikke umiddelbart passer ind i deres nuværende begrebs- og forståelsesverden. Den psykologiske tilgang til transformationer ses bl.a. hos professor emeritus Knud Illeris som bruger begreber som følelse, mentale skemaer og personlighed til at beskrive tranformativ læring som ændring af identitet (Illeris, 2006, 2013).

Det er ikke med dette kognitive, psykologiske fokus på elevernes tranformative processer, at denne artikels lærerideal skal forstås. Det transformative lærerideal trækker på pædagogiske og sociologiske begreber fra uddannelsesfilosof Gert Biesta, professor Hartmut Rosa og uddannelsesforsker Andrea English, som alle arbejder med begreber, som kan beskrive elevernes møde med modstand og vanskeligheder, ligesom de alle tre kan være med til at belyse, hvilken rolle erhvervsskolelæreren kan have. Samtidig er idealet også inspireret af en pragmatisk tænkning, hvor usikre situationer, tvivl og forvirring er med det at skabe refleksiv tænkning og udvikling (Dewey, 2009) Det er i en undervisning hvor eleverne møder opgaver, øvelser og aktiviteter de ikke forstår, som de betegner som vanskelige eller ikke kender til, at eleverne udvikler sig og skaber nye horisonter. Den amerikanske filosof John Dewey beskrev blandt andet den refleksive tænkning som;

\footnotetext{
at etablere de betingelser, der kan vække og styre nysgerrigheden, om at skabe sammenhæng i de oplevede ting, en sammenhæng, der senere vil fremme strømmen af spontane tanker og føre til formuleringen af problemstillinger og formål, der fremme sammenhængen, i tankestrømmen. (Dewey, 2009, s. 54)
}

Det tranformative læreideal lægger sig ikke direkte op af den refleksive proces som Dewey formulere, men er inspireret af de oplevelser som Dewey beskriver, hvor nysgerrighed, sammenhænge, tankestrømme og afprøvning bliver en del af det, at møde modstand. Dewey skriver blandt andet at 
Lærerrollen der blev væk

\begin{abstract}
...lærere, der har hørt, at de skal undgå emner, som er fremmede for elevernes erfaringer, overraskes ofte over, at børn vågner op, når de introduceres for noget, de ellers ikke kender til, mens de forbliver ligeglade, når de præsenteres for det, de i forvejen kender. (Dewey, 2009, s. 237)
\end{abstract}

Det er denne oplevelse, som idealet er inspireret af og vil forsøge at formulere igennem et tranformativt lærerideal. Idealet vil arbejde med at kvalificere, beskrive og begrunde et ideal, som formulerer erhvervsskolelærerens rolle og samtidig forsimpler den i henhold til tidligere beskrevet tendens til at mangfoldiggøre lærerrollen.

Formålet med et ideal er at give erhvervsskolelæreren en mulighed for at sigte efter noget, at forstå sin lærerrolle ud fra. Det betyder ikke, at idealet er et koncept som via formål og mål kan beskrive, hvordan læreren opnår en undervisningsmæssig succes. Idealet er muligheden for at arbejde med en konkret rolle og opgave som lærer, der styrker undervisningen, men som ikke er mulig at leve op til i alle undervisningssammenhænge. Deraf er undervisning i sin grundstruktur for ustyrlig, paradoksal og svær at detailstyrer og arbejdet med idealet bliver derfor at forestille sig undervisningen med risiko for, at man ikke altid lykkes (Biesta, 2014; English, 2014)

Jeg vil vende tilbage til, hvordan det transformative lærerideal kan formuleres og se ud, og vil for at begrunde idealet, i næste afsnit analysere tre transformative begreber, henholdsvis Gert Biestas begreb om modstand (Biesta, 2014, 2015, 2018), Hartmut Rosas begreb om resonans (Rosa, 2020; Rosa \& Endres, 2017) og Andrea Englishs begreb om productive struggle. (English, 2014; Murdoch m.fl., 2020)

\title{
Undervisning som modstand
}

Uddannelsesfilosoffen Gert Biesta udfolder igennem flere tekster og bøger sin argumentation for modstand og forstyrrelser i undervisnings- og uddannelsessammenhænge (Biesta, 2014, 2015, 2018). Biesta beskriver i bogen Undervisningens genopdagelse (2018), hvad der sker når eleverne i skolen møder modstand. Biesta mener at mødet med modstand er elevernes mulighed for at mærke og opleve at verden eksisterer ikke kun som en projektion af vores sind, men som en andethed, hvor verden opleves og skaber erfaringer og emancipation. Men modstand er genstridigt og svært at forholde sig til, og ofte vil man som lærer søge efter de aktiviteter, opgaver og øvelser, som eleverne kan få en umiddelbar succes med. Derfor vil eleverne i mødet med opgaver, øvelser og aktiviteter som yder modstand, ofte forsøge at nedkæmpe modstanden, dette kalder Biesta for verdensdestruktion, eller forsøge at undgå modstanden, ved at trække sig og dermed opleve det Biesta kalder selvdestruktion (Biesta, 2018, s. 37). Verdensdestruktion og selvdestruktion er modstandens to ekstremer som eleverne positionerer sig ved når modstanden ikke er velkommen, og de positioner som læreren vil 
forsøge at undgå, så eleverne i mødet med modstand i stedet oplever nye og anerledes erkendelser. Derfor formulerer Biesta også en mellemposition, en frustrerende gråzone (Johansen, 2017), som er her eleverne træder ind i mødet med modstanden og former en dialog, som er med til skabe erkendelser og følelsen af eksistens i verden. Mødet med modstanden bliver en mulighed for eleverne til at dvæle ved indholdet, undersøge det de arbejder med og omforme deres tænkermåder og ideer. Selvom om modstandens to ekstremer ifølge Biesta vil være tillokkende for eleverne at søge hen i mod (da de her let kan enten afvise eller tilintetgøre den undervisningssituation de er sat i) så er det lærerens rolle, at forsøge og skabe rammerne for mellempositionen. Det bliver lærerens rolle, at skabe et undervisningsrum hvor det at møde modstand anses som vigtigt, positivt og meningsfuldt (Biesta, 2018).

Man vil som erhvervsskolelærer skulle forsøge at udforme opgaver, øvelser og aktiviteter som skaber et møde mellem eleven og modstanden. Det kunne eksempelvis være de merkantile elevers møde med en svær kundecase, tømreelevernes møde med uigennemskuelige konstruktioner eller frisørelevernes møde med en ny og anderledes klippeteknik, hvor mødet med modstanden i første omgang nager, irriterer og skaber udfordringer, men hvor oplevelsen gerne skulle være med til, at skabe nye erkendelser om indholdet og eleverne selv som fagpersoner i verden. For sociologen Richard Sennett handler det om at identificere sig med og erkende modstanden, for deraf at kunne justere og omkonfigurere den, så man netop ikke afviser den eller lader sig opsluge af den, men forbliver i en mellemzone (Sennett, 2009, s. 224). I eksemplet med frisøren, skal frisøreleverne få en oplevelse af, at selvom den nye frisure med den nye klippeteknik fremstår vanskelig og svær, så kan arbejdet med den, give eleverne et perspektiv og nogle erkendelser af deres fag, som genkendelige instrumentelle teknikker ikke kan.

Biestas eksistentielle forståelse af mødet med modstand, bl.a. med reference til Hannah Arendt og Emmanuel Levinas, tager altså udgangspunkt i et ønske om at ville eksistere $i$ verden og møde og erfare, at verden ikke altid er som man ønsker (Biesta, 2015), og Biesta sætter dermed et lighedstegn mellem mødet med modstanden i undervisningen og det levede liv uden for undervisningen. Det bliver lærerens opgave at overbevise eleverne om, at undervisningens indhold, opgaver, øvelser og aktiviteter som yder modstand og er vanskelige og forstyrrer, tildeler eleverne en mulighed for at møde verden, erkende den og eksistere. Eleverne vil møde de samme typer af modstand ude i arbejdslivet, når de er færdige med deres uddannelse og pædagogikkens opgave er at skabe et refleksionsrum hvor dette møde kan opstå (Biesta, 2018). Eleverne skal ikke kun mødes med veldefinerede mål som de vejledes og faciliteres henimod, men også kunne fordybe sig i et indhold, som kan yde modstand gennem forskellige lærermæssige tiltag. 
Biesta skaber med sin forståelse af modstand en lærerrolle, hvor lærerne indgyder en modstand hos eleverne, som det er op til eleverne selv at bearbejde og forstå, med muligheden for at opnå nye erkendelser og udvikle sig. Den umulige kundecase hos de merkantile elever kan måske ikke nødvendigvis løses med det samme ud fra kendte teorier og begreber, men den kan være med til at give eleverne en oplevelse af, hvordan den merkantile verden ser ud og hvordan eleverne selv kan indfinde sig i den.

\section{Resonans og det knitrende klasseværelse}

Den tyske professor og sociolog Hartmut Rosas udgangspunkt for en transformativ oplevelse, er en hypotese om, at den menneskelige verden opleves som modstand. Rosa forsøger fænomenologisk at forstå, hvad det er som knitre i undervisningen og antyder samtidig, at mødet med modstand er en form for grundvilkår for den menneskelige væren og essensen af de relationer vi møder og oplever i verden. Rosa bruger begrebet resonans (Rosa, 2020; Rosa \& Endres, 2017), som en måde at beskrive de relationelle forhold, individet kan møde i forskellige former for ukontrollerbare oplevelser. På samme måde som Biesta betoner Rosa en mellemposition for mødet med modstanden, når han skriver:

For faktisk kan vi kun opleve resonans mellem mennesker og ting, når de så at sige er "halvkontrollerbare", når de bevæger sig mellem total kontrollerbarhed og det helt ukontrollerbare. (Rosa, 2020, s. 39)

Hvis mødet med modstand er et menneskeligt vilkår, peger denne forståelse på, at eleverne på erhvervsuddannelserne gennem læreren skal møde forskellige former for modstand, som en del af en helhedsorienteret undervisning.

Rosa oplister fire kendetegn på resonans; påvirkning, selvvirksomhed, forvandling og det ukontrollerbare (Rosa, 2020) I påvirkningen er det menneskets møde med et andet menneske som skaber resonans. Det er oplevelsen af impulser som opstår i dette møde som skaber oplevelsen. Erhvervsskolelærerne møder eleverne med fagets formål, mål og indhold og eleverne møder lærerne med forventninger, krav og nysgerrighed til faget. Hvis den gensidig påvirkning lykkes, vil eleverne opleve og udvikle en indre interesse for faget, og læreren vil opleve at eleverne responderer på det som bliver præsenteret for dem. Læreren ville kunne mærke at eleverne bliver påvirket og ikke passivt acceptere det de bliver mødt med.

Dette møde med resonans sker dog ifl. Rosa først når man som individ også responderer på den påvirkning man møder. Som elev møder man ikke kun lærernes intentioner med et tomblik og en opgivende rysten på skuldrene, men accepterer påvirkningen som en interesse i sig selv og en nysgerrighed, som fører til en dannelsesmæssig udvikling, deraf selvvirksomheden. Rosas beskrivelse af 
mødet med resonans minder om Biestas mellemzone, hvor eleverne også accepterer den modstand de mødes med. Som lærer og elev bevæger man hinanden, og dette sker bl.a. når det lykkes læreren at skabe et knitrende undervisningsrum (Rosa \& Endres, 2017). Ud fra mine egne tidligere observationer fra struktøruddannelsen, var det tydeligt at fx værkstedsundervisningen ofte kan opleves som et knitrende undervisningsrum, hvor eleverne har gang i flere forskellige processer på samme tid og hvor eleverne både overvejer deres arbejde, diskutere det med læreren og frustreres over det med deres klassekammerater (Skov, 2020)

Rosa beskriver det tredje kendetegn som en transformativ proces, hvor menneskets møde med påvirkningen forvandler dem i forhold til verden. Her ses i særdeleshed en dannelsesmæssig figur, hvor eleverne oplever, at de påvirkninger de møder er med til at skabe nye forståelser og skabe muligheden for at se sig selv på en anden og ny måde. Leo Kommicke-Konnerup skriver med udgangspunkt i den tyske professor Klaus Prange, at det i arbejdet med håndværket for eleverne ikke kun handler om tekniske færdigheder, men også om fx moralske dyder (Komischke-Konnerup, 2019). Her stifter eleverne gennem resonans bekendtskab med flere sider af deres erhvervsuddannelse og forstår eksempelvis deres fag som andet end opfyldelsen af bekendtgørelsen for faget. Tømrereleven forstår ikke kun sine håndværksmæssige kompetencer, som evnen til at bygge et hus, men også hvordan huset kan blive hjemmet for en familie, hvor børn kan vokse op og hvor forskellige liv kan formes, leves og udvikles. På den måde kan tømrereleven komme til at erkende sig selv og sit fag, som et væsentligt biddrag til verden.

Det sidste kendetegn hos Rosa handler om det ukontrollerbare som et grundlag for resonans. Mødet med resonans kan aldrig kontrolleres, og det ukontrollerbare vil altid være et vilkår i større eller mindre omfang, også i undervisningen. Erhvervsskolelæreren kan aldrig garantere eleverne en oplevelse af resonans, men læreren kan understøtte muligheden for, at eleverne oplever det ved at skabe en undervisning, som forholder sig til det ukontrollerbare. Hvis eleverne skal møde modstand og opleve resonans sker det ikke igennem en undervisning som er grundlæggende stabil, tryghedsskabende og let, men igennem en undervisning som først bliver essentielt og eksistentiel vigtig med en manglende kontrol og en følelse af uoverensstemmelse (Brunstad, 2010; Lindseth, 2014)

På flere måder taler Biesta og Rosa begge ind i et transformativt lærerideal, hvor lærerens opgave bliver at planlægge og fordre en ukontrollerbar undervisningsform, hvor eleverne kan opleve at møde modstand fra enten læreren eller indholdet, en modstand som kan irritere og vanskeliggøre arbejdet med undervisningsaktiviteterne, men som også skaber grundlaget for nye dannelsesmæssige erkendelsesformer. 


\section{Diskontinuitetens pædagogik}

Uddannelsesforsker Andrea English arbejder i sin fortolkning af transformationer med begrebet productive struggle (English, 2014; Murdoch m.fl., 2020) som tager udgangspunkt i teoretiseringer over diskontinuiteter med hovedsagelige referencer til Johan Friedrich Herbart og John Dewey. English er den af Biesta, Rosa og hende selv som kommer tættest på at beskrive en tydelig lærerrolle ift. hvordan læreren skal agere i undervisningen. Jeg vil her både analysere begrebet productive struggle og lærerens rolle hos English.

English begrunder sin position med den misforståelse, at læreren kan prædeterminere hvad eleven forventer og ikke forventer af det materiale de bliver præsenteret for, og at læreren skal forsøge gøre undervisningen forventelig (English, 2014, s. 25). I denne forståelse vil læreren hele tiden fokusere på, at den nye viden som eleven skal tilegne sig, hænger sammen med den viden eleven har i forvejen, $i$ en form for assimilativ proces. English kritiserer her indirekte denne artikels udgangspunkt, nemlig et for stort fokus på at gøre læringsprocesserne lette og lærerens rolle som alt andet end en lærer. Det er, mener English, når eleverne har transformative oplevelser, at det virkelige lærings- og dannelsespotentiale står frem. Det er når eleverne opdager, at de ikke ved det hele på forhånd og gennem mødet med diskontinuitet, oplever at verden åbner sig på ny. På den baggrund bliver det lærerens rolle at kultivere en indre konflikt hos eleverne, og bringe nye og andre perspektiver ind, som modsiger elevenernes nuværende viden og forståelser. Eleverne skal igennem en oplevelse af fornyet bevidsthed, forstå sig selv på nye måder og transformere deres viden over i nye muligheder og perspektiver. (English, 2014).

Når eleverne bringes i de overnævnte situationer, oplever de productive struggle (English, 2014, s. 124; Murdoch m.fl., 2020), en produktiv modstand, som åbner verden for eleverne. Med reference til især Herbart beskriver English lærerens rolle med at skabe productive struggle som en moralsk guide, som ikke skal fortælle eleverne, hvad der rigtigt eller forkert, eller hvilken vej de skal gå (English, 2014, s. 33). I stedet skal læreren understøtte elevernes oplevelser med at møde modstand og give eleverne mulighederne for selv at arbejde med, hvad de rigtige og forkerte løsninger kan være. Det er en respekt for elevernes frihed og muligheden for at udøve selvkritik og udvikle sig selv.

I define the educational relation as the relation between teacher and learner that supports the learner's striving toward moral self-determination and thus neither imposes the will of the teacher onto the learner nor forces the learner to blindly conform to societal norms. (English, 2014, s. 43)

Englishs perspektiv ses blandt andet også hos den franske filosof Jacques Ranciére, som argumenterer for den udvidende lærer, som sætter eleverne fri og lader dem arbejde med indholdet. Her understøtter læreren eleverne med at blive på 
sporet, så de forsætter med at være nysgerrige og søgende på det givne indhold (Ranciére, 2020).

Med forsøget på at skabe productive struggle beskriver English lærerens kompetence til, at lytte til eleverne. At lytte til eleverne handler om fornemme og overveje, hvornår eleverne har brug for at blive kultiveret med modstand, hvor spørgsmål og overvejelser bruges til at bringe eleverne i konflikt med undervisningsaktiviteterne og skabe forudsætningerne for transformationer (English, 2014, s. 44). Lytterollen bliver lærerens værktøj til at vide, hvornår eleverne har brug for at blive udfordret på deres overvejelser, holdninger og egeninteresser. Netop denne evne til at forstå, lytte, fornemme og overveje er det English med en reference til Herbart kalder pædagogisk takt (English, 2014).

English peger i lighed med Rosa på lærerens rolle i at bringe eleven frem til mødet med modstanden. Læreren har en rolle med at lytte og forstå, hvordan og hvornår eleverne har de optimale rammer for ikke kun at møde modstanden, men også acceptere og arbejde med den.

\section{Tegningerne til et transformativt lærerideal}

På baggrund af analysen af begreber fra Biesta, Rosa og English vil dette afsnit skitsere, hvad der kan forstås med et transformativt lærerideal. Samlet peger Biesta, Rosa og English alle på modstanden som et menneskeligt vilkår og et møde, som er med til at skabe mennesket. Med det grundlag bliver det transformative lærerideal et ideal hvor erhvervsskolelæreren indgyder og skaber forudsætningerne for mødet mellem modstanden og eleven. Mødet med modstanden skal ikke slå eleven ud af kurs eller få eleven til at afvise indholdet, men kultivere eleven, og give ham eller hende mulighed for at komme i en zone hvor modstanden accepteres, bearbejdes og understøtter nye erkendelser.

Det transformative lærerideal forsøger altså ikke at drive erhvervsskoleeleverne på vildspor. Tømrerlæreren vil ikke bede eleverne om at konstruere arbejdstegninger, de ikke har forudsætningerne til eller har lært på uddannelsen endnu. Tømrerlæreren vil i stedet lade eleverne møde forskellige træsorter, som reagerer forskelligt når de bliver bearbejdet og lade eleverne møde håndværksopgaver, som ikke har et prædefineret svar, eller lade eleverne møde cases fra tømrervirksomheder, som giver dem muligheden for at reflektere over, hvilken håndværker de gerne vil blive. Den merkantile lærer vil heller ikke fremsætte umulige og urealistiske butikscases for sine elever, men måske i stedet føre dem mod at arbejde med forskellige dilemmaer fra butiksverdenen (udfordrende kunder eller hvordan man som butiksejer forholder sig til Covid-19 restriktioner), som ved deres løsningsforlag skaber nye dilemmaer. Og kokkelæreren vil ikke slavisk gennemgå en konkret madopskrift med eleverne, men lade dem være i frustrationen over ikke nødvendigvis at kende til rettens afsluttende udseende eller hvornår de enkelte tilberedninger reelt kan betragtes som færdigtilberedte. 
Det handler for erhvervsskolelæreren om at finde de steder i undervisningen, som har potentiale til at yde eleverne produktiv modstand, hvad enten det er indholdet, opgavernes udtryk eller undervisningens form.

Både Rosa, Biesta og English iscenesætter læreren som den afgørende faktor for eleverne og hvis eleverne skal lære noget, skal læreren ikke præsentere forenklede og lette løsningsopgaver for dem, men i stedet være faktoren som skaber følelsen og muligheden for resonansoplevelser. Eleverne oplever ikke resonans eller modstand ved, at læreren indtager en hel række af forskellige roller og positioner og gøre undervisningen let for eleverne.

Med det transformative lærerideal handler det for erhvervsskolelæreren i stedet om at skabe et undervisningsrum, hvor eleverne ikke blot skal lære af en opgave, som læreren efterfølgende via konkrete mål kan vurdere om er løst korrekt eller ej. Det erhvervsskolelærerens opgave at se og lytte på eleverne for at vurdere, hvordan og hvornår i undervisningen der kan sættes ind med en kultivering af eleverne og hvornår det ukontrollerbare sættes i scene. For både English og Biesta indbefatter det også, at løbe en risiko, når man som lærer ikke er sikker på, at de tiltag man sætter i gang i sin undervisning, rent faktisk også vil lykkes, og eksempelvis skabe modstand (Biesta, 2014; English, 2014) Der vil altid være en mulighed for, at undervisningen mislykkes, eller som med Biestas modstandsdistinktion, at eleverne ender i destruktive positioner, i stedet for transformative oplevelser.

Man kan naturligvis rejse en kritik af det transformative lærerideal for måske at gøre eleverne dygtigere end de egentlig er og ligge til grund, at eleverne altid af natur vil acceptere at bringes i transformative situationer. Eleverne bliver nødt til at have nogle grundlæggende faglige og undervisningsmæssige forudsætninger for overhovedet at kunne møde modstand. Man vil også kunne kritisere idealet for en mulig romantisering af undervisningen, som ikke tager højde for hvad man som lærer gør, hvis elevernes i sidste ende ikke opnår de målpinde, som er grundlaget for at kunne gennemføre uddannelsen. Der er ingen erhvervsskolelærere som ønsker at give deres elever en oplevelse af, at de altid sættes i positioner hvor tingene er svære, eller hvor succesoplevelsen i løsningen af en given undervisningsaktivitet ikke stod mål med oplevelsen af, at aktiviteten var vanskelig og ydet modstand. Det transformative lærerideal kan sagtens udsættes for en sådan kritik, men samtidig argumenterer idealet for at kunne leve op til en tydelig helhedsorienteret undervisning, hvor mødet med modstand i form at forskellige vanskelige opgaver, viser eleverne deres fag i virkelige situationer, som en virkningsfuld vekseluddannelse. Det handler ikke om at gøre undervisningen så svær for eleverne at de vælger den fra, men planlægge de rette undervisningsmæssige rammer for, at elevernes møde med modstand bliver et frugtbart møde, hvor undervisningsaktiviteterne nok er vanskelige og kan skabe forhindringer, men hvor det for eleverne også kan ses som erkendelsesmæssige muligheder. Det 
kræver at eleverne i en eller anden grad også kender deres fag og at undervisningen er tilpasset eleverne, så modstanden ikke bliver til negative forhindringer, men positive bekendtskaber.

Med det transformative lærerideal mener jeg, at erhvervsskolelæreren får sin oprindelige lærerrolle igen, hvor udgangspunkt er indholdet og hvor erhvervsskolelæreren med sin viden bliver omdrejningspunktet for undervisningen. Det bliver et lærerideal, som med en let inspiration fra en uren pædagogik (Brinkmann m.fl., 2011) tager udgangspunkt i lærerens rolle og fagets indhold, og derigennem skaber en sammenhæng, hvor eleverne arbejder konkret, nysgerrigt og fordybende med indholdet, og i den proces møder modstand som er med til at udvikle og danne dem. På samme vis understøtter læreridealet erhvervsuddannelsernes vekseluddannelsesprincip som hviler på en tanke om en sammenhæng mellem skole og virksomhed. Denne vekselvirkning har især sin styrke i, at lade eleverne møde forskellige former for modstand i deres fag, som kan relateres til den modstand, som eleverne også ville møde i det arbejdsliv de efter endt uddannelse bliver en del af. Erhvervsuddannelserne understøtter deraf sit eget formål som et sted, der er med til at danne og uddanne elever, som både er klar på at møde erhvervets udfordringer, men som også er i stand til at være i den modstand de møder, hvor tålmodighed og identifikation med modstanden, hos fx en håndværker, udtrykker en evne til at fastholde en frustrerende opgave (Sennett, 2009).

Med det transformative lærerideal bliver et dannelsesprojekt på erhvervsuddannelserne også mere synligt, hvor mødet med det ukendte skaber en sammenhæng mellem uddannelse og verden. Dannelsesfiguren hjem-ud-hjem kan ses som en transformationsforståelse, hvor mødet med verden, udeheden og det ukendte i sidste ende bringer eleverne hjem igen, med nye perspektiver og erkendelser.

\section{Afslutning}

Jeg har i artiklen forsøgt at formulere et transformativt lærerideal som en anden forståelse af erhvervskolelærerens rolle som lærer. Med udgangspunkt i en moderne tendens til at tillægge læreren forskellige og mindre gennemsigtige rollebetegnelser, og med tendens til at tænke læring som lærerunderstøttelse, målstyring og forsimpling af undervisningsaktiviteter, blev et alternativt lærerideal begrundet.

Med udgangspunkt i en filosofisk analyse af begreber fra Gert Biesta, Hartmut Rosa og Andrea English blev fokus flyttet fra de mange mere eller mindre uforståelige og ofte udefinerede lærerroller, til et lærerideal med fokus på en transformativ tilgang. Her er det erhvervsskolelæreren, som iscenesætter indholdet og gennem didaktiske valg, tiltag og forskellige møder med det faglige indhold, 
skaber en mulighed for at eleverne kan møde modstand. Mødet med modstanden skaber et udgangspunkt for, at eleverne ikke entydigt lærer frem mod konkrete definerede målpinde, men arbejder med et indhold, som i sidste ende ikke kun gør at de lærer noget om og fra deres fag men også erkender, danner og udvikler sig.

\section{Om forfatteren}

Tobias Kidde Skov, adjunkt, VIA University College. Tobias arbejder med udvikling af pædagogisk og uddannelsesmæssig tænkning samt underviser på Diplomuddannelse i Erhvervspædagogik. 


\section{Referencer}

Beck, S. (2016). Pædagogikum mellem teori og praksis- en brugsbog til de almendidaktiske moduler. Frydenlund.

Biesta, G. (2014). Den smukke risiko: I uddannelse og pædagogik. Klim.

Biesta, G. (2015). Hvad skal vi stille op med børnene? Om uddannelse, modstand og dialogen mellem barn og verden. I J. Klitmøller \& D. Sommer (Red.), Læring, dannelse og udvikling: Kvalificering til fremtiden $i$ daginstitution og skole (s. 105-122). Hans Reitzel.

Biesta, G. (2018). Undervisningens genopdagelse. Klim.

Brinkmann, S., Aastrup Rømer, T. \& Tanggaard, L. (2011). Uren pædagogik. Klim.

Brunstad, P. O. (2010). Diskontiuitetens pegagogikk. I S. Rise (Red.), Danningsperspektiver: Teologiske og filosofiske syn på danning $i$ antikken og $i$ moderne tid (s. 241-259). Tapir akademisk forlag.

Dewey, J. (2009). Hvordan vi tænker (Dewey biblioteket). Klim.

English, A. R. (2014). Discontinuity in Learning: Dewey, Herbart and Education as transformation. Cambridge University Press.

Holm Sørensen, B., Audon, L. \& Tweddell Levensen, K. (2010). Skole 2.0. Klim.

Illeris, K. (2006). Læring. Samfundslitteratur.

Illeris, K. (2013). Transformativ læring og identitet: Kunsten at forblive et rigt samfund. Samfundslitteratur.

Johansen, M. B. (2017). "En frustrerende gråzone" - Gert Biesta og den uddannelsesmæssige betydning af modstand. I O. Morsing \& L. Granjean (Red.), Uddannelse for en menneskelig fremtid: Gert Biestas pædagogiske tænkning (s. 35-50). Klim.

Komischke-Konnerup, L. (2019). Prange og pædagogik: Pædagogisk praksis som håndværk. I A. Von Oettingen (Red.), Pædagogiske tænkere: Bidrag til empirisk dannelsesforskning (s. 185-196). Hans Reitzels Forlag.

Kaatmann, S. (2021). Den faciliterende underviser. EMU.dk. https://emu.dk/eud/paedagogik-og-didaktik/praksisbaseret-og-anvendelsesorienteret-undervisning/den-faciliterende

Lindseth, A. (2014). Svarevne og kritisk refleksjon: Hvordan utvikle praktisk kunnskap? I J. S. Methi \&. J. McGuirk (Red.), Praktisk kunnskap som forskning: Antologi over yrkeserfaringer som utgangspunkt for fortsåelse av kunnskapsutvikling i praksis (s. 43-60). Fagbokforlaget.

Murdoch, D., English, A., Hintz, A. \& Tyson, K. (2020). Feeling heard: Inclusive education, transformative learning, and productive struggle. Educational Theory, 70(5), 653-679. https://doi.org/10.1111/edth.12449

Ranciére, J. (2020). Den udvidende lærer: Fem lektioner i intellektuel emancipation. Antipyrine.

Rosa, H. (2020). Det ukontrollerbare. Eksistens. 
Rosa, H. \& Endres, W. (2017). Resonanspædagogik: Når det knitrer i klasseværelset. Hans Reitzels Forlag.

Rømer, T. A. (2010). Uddannelse i spænding: Åbenhjertighedens, påmindelsens og tilsynekomstens pædagogik. Klim.

Rømer, T. A. (2017). Undervisningens gavegivning. Studier i læreruddannelse og -profession, 2(1), 73-89. https://doi.org/10.7146/lup.v2i1.27689

Sennett, R. (2009). Håndværkeren - Arbejdets kulturhistorie: Hånd og ånd. Hovedland.

Skov, T. K. (2020). Dannelse i et videnskabsteoretisk perspektiv. I A. Gudnason, \& H. Hersom (Red.), Sandheder og menneskesyn: Pædagogisk videnskabsteori for erhvervsskolelærere (s. 186-193). Praxis.

Svejgaard, K. L. (2011). Rød, gul og grøn: En metode til undervisningsdifferentiering. NCE Metropol.

Tanggaard, L. (2017). Hvor blev 'undervisningen' af? KVAN - et tidsskrift for læreruddannelsen og folkeskolen, 37(107), 70-79. 